考えて提案している7。

この回転円筒型の脱水機は，ドラムを回転するため の動力以外は不要であり, ドラム内部は単なる仕切板 のみで動く部分をもたず，また沪布を用いていないこ とが特徵といえよう。

現在, この型の脱水機は砂利洗浄排水, シールド工 法のペントナイト泥水, 自動車工場の排水処理スラッジ, 上水道の浄水場スラッシ，河川の浚渫スラッジなどに適 用されており，得られる脱水ヶーキの含水率は，同一の スラッジを真空ろ過機にかけたときに得られるヶーキと ほぼ同じである。処理能力はスラリの性質によって異な り, 砂利洗浄排水のような粘土質のとき, $1.9 \mathrm{~m}$ (直径) $\times 5.4 \mathrm{~m}$ (長さ) のデハイドラムで約 $5 \sim 7$ ton·solid/hr である。

\section{記号の説 明}
$A=$ 沈降分離面積
$C=$ 湄度
$C_{0} \quad=$ 最初の濃度
$p_{m}=$ 沈浲速度が $u_{0}$ より小さい粒子の百分率

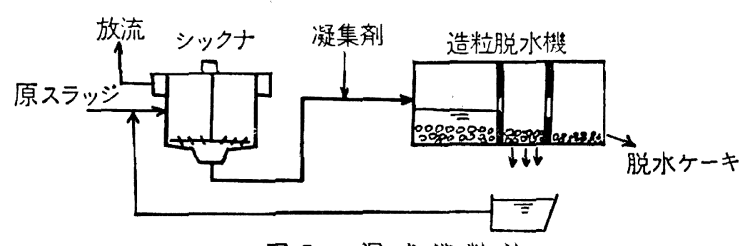

図 7 湿式造粒法

$$
\begin{aligned}
Q & =\text { 排水流量 } \\
u_{0} & =\text { 沈降速度 }=Q / A \\
v & =\text { 溢流速度 } \\
z & =\text { 水面からの深さ } \\
\theta & =\text { 時間 } \\
\eta & =\text { 分離効率 }
\end{aligned}
$$

$\left[\mathrm{m}^{3} / \mathrm{hr}\right]$ $[\mathrm{m} / \mathrm{hr}]$ $\left[\mathrm{m} / \mathrm{hr}\right.$ または $\left.\mathrm{m}^{3} / \mathrm{m}^{2} \cdot \mathrm{hr}\right]$

\title{
参考文献
}

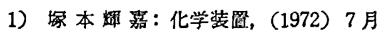

2) Camp, T.R.: Sewage and Ind. Wastes, 25, No.1 (1953)

3）井出哲夫：水処理技衍， 3, No.9 (1962)

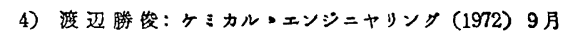

5）洨辺勝俊 5 ：昭和” 48 年度下水道研究発表会 (1973)

6) 铃木英友: 第 59 回化学装䁌愁話会 (昭 $47 \cdot 2$ 月)

7) 遊佐美津雄: 第 1 回環境保全䓅衍詶座（昭 $47 \cdot 12$ 月）

\section{- 有害物質の除去技術と装置設計上の問題点}

\section{i) 物理処理・化学処理による除去}

\section{1. 有害物啠の種類と排水基準}

水質污染防止法に上れば排水の水質基準に関して有害

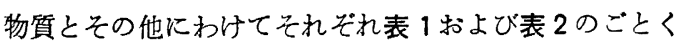
示されている。さらに都道府県は独自の判断によってよ りきびしい基準を決めることができるとされている。こ の中, SS を除いてはすへでが溶存物質と言ってよいも のであり, 本稿ではこれらの溶存有害物質の物理処理, 化学処理による除去技術について述べる。な㨬に示さ れていないものであっても色, 臭, 泡なども排水の水質

* 昭和 48 年 3 月 23 日受理

** Hiroshi Shimizu (正会員) - Akimitsu Miyahara (正会員) オルガノ株式会社
清 水 博**.宮 原 昭 三**

として必らず問題になるものである。

\section{2. 物理処理, 化学拠理による除去技術}

溶存有害物質 (本稿では表 1 , 表 2 を含めてすべての 污染物質といら意味で使用する）は非常に種類が多く従 ってその除去技術も多種多様である。これを除去方法の 原理によって分類してみると次のようになる。

i）有害物質を無害化する方法

ii）有害物質を沈股として除去する方法

iii）有害物質を四着剂で四着除去する方法

iv）有害物質を膜で分雖除去するす法

以下，打の打のについて現在実際に使用されている技 
表 1 有害物澌のー般基萍

\begin{tabular}{|c|c|}
\hline 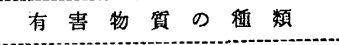 & 許容限度 $[\mathrm{mg} / \mathrm{ll}]$ \\
\hline $\begin{array}{l}\text { カドミウム掘よびその化合物 } \\
\text { シアン化合物 }\end{array}$ & $\begin{array}{ll}\mathrm{Cd} & 0.1 \\
\mathrm{CN} & 1\end{array}$ \\
\hline 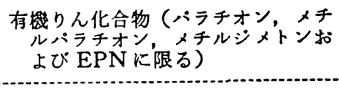 & 1 \\
\hline $\begin{array}{l}\text { 鉛およびその化合物 } \\
6 \text { 価クロム化合物 }\end{array}$ & $\begin{array}{cc}\mathrm{Pb} & 1 \\
6 \text { 洒 } \mathrm{Cr} & 0.5\end{array}$ \\
\hline ひ妻扰よびその化合物 & As $\quad 0.5$ \\
\hline $\begin{array}{l}\text { 水銀执上びアルキル水銀その他の水 } \\
\text { 銀化合物 } \\
\text { アルキル水銀化合物 }\end{array}$ & $\begin{array}{l}\mathrm{Hg} \text { につき不検出 } \\
\text { 不榆出 }\end{array}$ \\
\hline
\end{tabular}

[注］不険出とは定量限界を下回ること

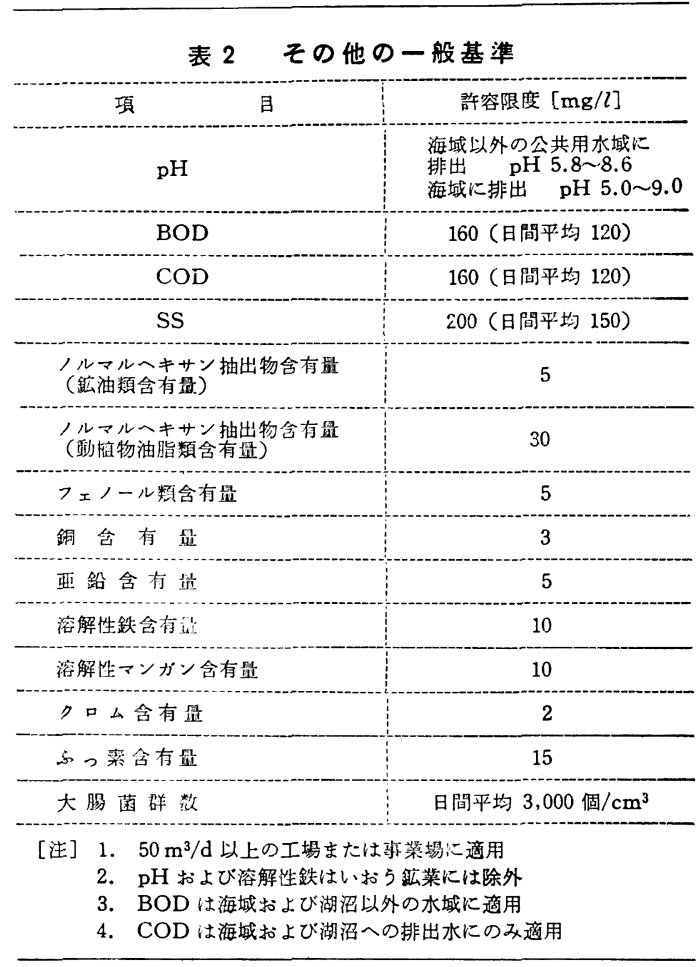

術を説明しよう。

\section{$2 \cdot 1$ 有害物質を無害化する方法}

有害物質の分子構造を化学反応により変化させ無害化 するものでその最も簡単な例が中和である。

中和は最も簡単な化学反応である。しかし $\mathrm{pH}$ 変動が 大きく, しかも大量であり, かつ流量の変動も大きい場 合にはこれらを規定の $\mathrm{pH}$ 籁囲に中和することは容易で はない。海域に排出する場合の $\mathrm{pH} 5.0$ 9.0 といら值を $\mathrm{H}^{+}$または $\mathrm{OH}^{-}$の濃度で表わすと $1 \mathrm{ppm}$ as $\mathrm{CaCO}_{3}$ 以 下の濃度であり, 排水中の酸, アルカリの量に見合った 中和剂を加兄て最終的に $\mathrm{H}^{+}$をたは $\mathrm{OH}^{-} の$ 濃度を 1 $\mathrm{ppm}$ as $\mathrm{CaCO}_{3}$ にしなければならない。中和剤の添加 量をどんな風にして調節するか，拈よび反応を均等に進

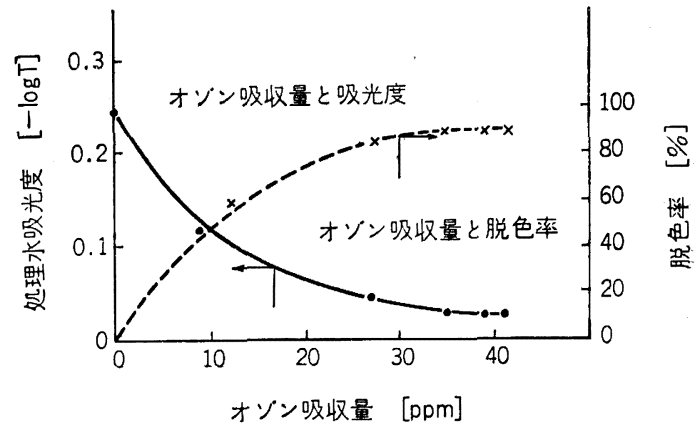

图 1 オソ゚ン吸収量と染色排水の脱色

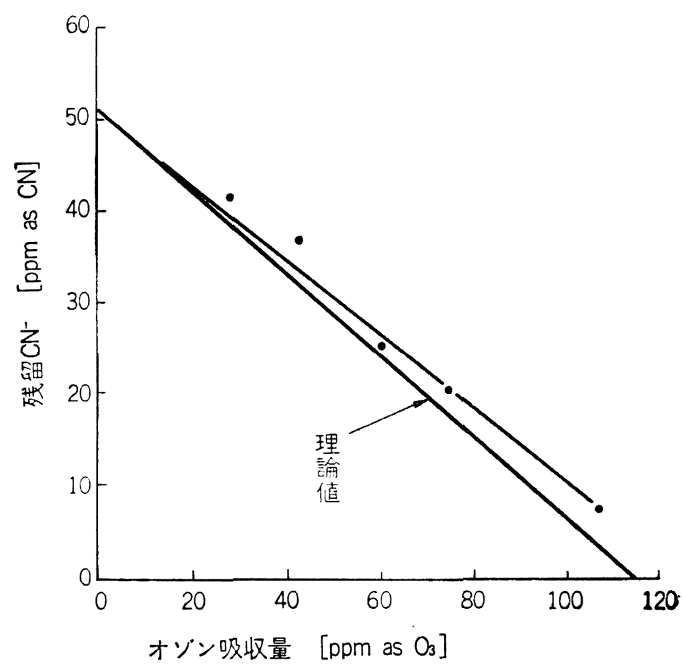

图 2 オゾンによる $\mathrm{CN}^{-}$の酸化分解

行させるための擋拌方法が中和法の現実的な問題点であ る。中和剤としては, $\mathrm{HCl}, \mathrm{NaOH}$ が取扱いが容易であ るが，価格の点から $\mathrm{H}_{2} \mathrm{SO}_{4}, \mathrm{Ca}(\mathrm{OH})_{2}$ を用いる場合も 多い。この場合には $\mathrm{CaSO}_{4}, \mathrm{CaCO}_{3}$ などの沈殿を生ず ることがあるので注意を要する。擋拌には機械的方法や 空気による方法が用いられる。

無害化するための化学反応として用いられる別の反応 は酸化である。酸化戍としては塩亲系の化合物が主とな って用いられて来たが，近年オゾンが検討されている。

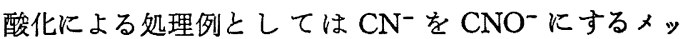
キ排水の処理, 処理下水の殺菌, 着色排水の脱色なとかが ある。たた塩素系の酸化剤を用いる時に注意しなければ ならないのは水の中に有機物が存在している時, 有害な 有機塩素化合物を生ずる場合があることである。これに 対しオゾンによる酸化にはそのような心配がなく，ま た電気さえあれば空気を原料にして合成し得るといら特 徵がある。しかし処理後の水やガス中の残留オゾンに関 して注意する必要がある。オソンによる染色排水の脱 色， $\mathrm{CN}^{-}$の分解，ABS の分解などの実験結果を図 1 3 に示す。 


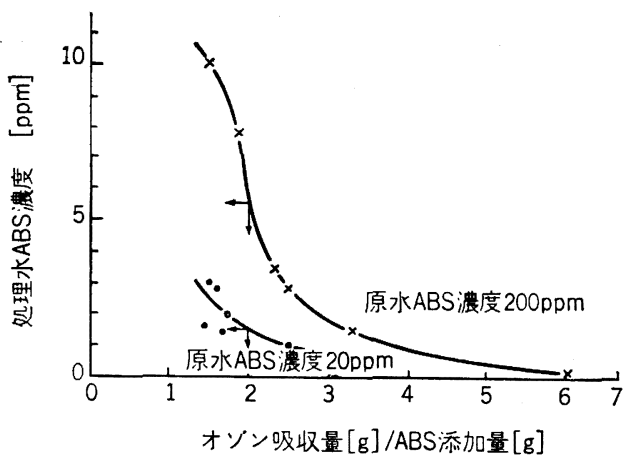

图 3 オソン添加甼と処理水中の ABS

以上の酸化は有機物に対して脱色の効果はあるが， COD や BOD の除去に対してはあまり効果がない。有 機物の酸化を完全に行なら方法としては高濃度排水を処 理するための水中燃焼法がある。水中然焼法は排水に空 気を吹き込み，数十 $\mathrm{kg} / \mathrm{cm}^{2}$ に加圧， $200^{\circ} \sim 300^{\circ} \mathrm{C}$ に加 熱して処理するものである。主として有機性のスラッシ の処理に使用されている。本方法はスラッジ処理の項で 詳しく説明されると思う。

\section{$2 \cdot 2$ 有害物質を沈澱として除去する方法}

凝集処理は本来微細㲘濁物質を除去する方法である が，凝集剤によってフロックが生成する時，溶解してい る有機物がフロックに吸着されることもある。しかし沈 殿法の一般的なるのは重金属の除去である。これは重金 属を溶解度の小さい化合物に変えるものであり，具体的 には下記の 3 方法が利用されている。

。水酸化物とする

○硫化物とする

○有機物と結合させる。たとえばザンセート錯塩とする。

有害重金属の水酸化物, 硫化物の溶解度を表 3,4 に示 す。析出した沈殿は㲘濁物質の除去技術によって処理す る。

沈殿法では理論值としての表 3 や，表 4 の值が目標で あるが，実際には共存物の影響や反応条件の不完全さの ためにこれを上回ることが多い。沈殿剤の添加量や反応 装監の設計に留意することが必要である。

\section{$2 \cdot 3$ 有害物質を吸着剂で吸着除去する方法}

活性炭，イオン交換樹脂，その他がある。

活性炭は水中の有機物吸着剤として糖液その他の脱色 に古くから広く使用されているが，排水処理に関しても 今や重要な役割を果している。特に良質の粒状活性炭が 製造されるよらになり，さらに焙焼再生技術の確立によ って吸着した有機物を分解し気化させてしまらのでスラ ッジ処理が伴わない有機物含有排水の処理法としてすく れている。しかし活性炭に対して吸着されやすい有機 物とそうでないるのとあるので， あらかじめ実験で確か
表 3 重金属水酸化物の溶解度

\begin{tabular}{l|l}
\hline 重金属水酸化物 & \multicolumn{1}{|c}{ 溶 } \\
\hline $\mathrm{Cd}(\mathrm{OH})_{2}$ & $1.2 \times 10^{-5} \mathrm{~mol} / l\left(25^{\circ} \mathrm{C}\right)$ \\
$\mathrm{Cr}(\mathrm{OH})_{3}$ & $1.2 \times 10^{-8} \mathrm{~mol} / l\left(20^{\circ} \mathrm{C}\right)$ \\
$\mathrm{Cu}(\mathrm{OH})_{2}$ & $3.0 \times 10^{-5} \mathrm{~mol} / l\left(25^{\circ} \mathrm{C}\right)$ \\
$\mathrm{Ni}(\mathrm{OH})_{2}$ & $1.27 \times 10^{-3} \mathrm{~g}$ 無水物 $/ 100 \mathrm{ml}\left(20^{\circ} \mathrm{C}\right)$ \\
$\mathrm{Zn}(\mathrm{OH})_{2}$ & $1.92 \times 10^{-9} \mathrm{~mol} / l\left(20^{\circ} \mathrm{C}\right)$ \\
\hline
\end{tabular}

\section{表 4 重金属硫化物の溶解度}

\begin{tabular}{|c|c|}
\hline 重金属硫化物 & 解 \\
\hline $\mathrm{As}_{2} \mathrm{~S}_{3}$ & $5.2 \times 10^{-5} \mathrm{~mol} / l \quad\left(18^{\circ} \mathrm{C}\right)$ \\
\hline $\mathrm{CdS}$ & $1.46 \times 10^{-10} \mathrm{~mol} / l \quad\left(25^{\circ} \mathrm{C}\right)$ \\
\hline $\mathrm{HgS}$ & $3 \times 10^{-52 *} \quad\left(18^{\circ} \mathrm{C}\right)$ \\
\hline $\mathrm{CuS}$ & $2.55 \times 10^{-15} \mathrm{~mol} / l \quad\left(25^{\circ} \mathrm{C}\right)$ \\
\hline $\mathrm{NiS}$ & $2 \times 10^{-21 *} \quad\left(25^{\circ} \mathrm{C}\right)$ \\
\hline $\mathrm{PbS}$ & $3.62 \times 10^{-11 *} \quad\left(25^{\circ} \mathrm{C}\right)$ \\
\hline$Z_{n S}$ & $1.47 \times 10^{-9} \mathrm{~mol} / l \quad\left(20^{\circ} \mathrm{C}\right)$ \\
\hline
\end{tabular}

* は溶解度喑を示す

める必要がある。粒状活性炭の問題点は反応速度が遅い ことである。從って粒状活性岸を塔に充填して排水を処 理する時, 10〜30 分以上の接触時間をとらねばならず装 直が必然的に大きくなる。また洩出曲線が非常になだら かになるため, 処理水水質がある基準値に達した所で処 理を止めると飽和吸着量に対する有効使用吸着量が小さ くなってしまら。有効使用吸着量を增大させるためには 多塔式にすれば良いが，建設費の増大を招いてしまら。 排水のように種々の有機物を含む場合の粒状活性炭によ る吸着について最も効率的な設計技術を確立することが 要望される。粒状活性炭には水中の重金属を吸着する性 能もある。水銀とかクロムなとは非常によく吸着され る。溶離に関してまだ充分な検討がされていないが興味 ある現象であり，実用の可能性もあるのではないだろう 加。

イオン交換樹脂は重金属が主な対象である。イオン交 換樹脂は多価イオンや錯イオンに対して選択性を持って おり，この性質が有害物質除去に利用される。たとえば 水銀の錯アニオン $\mathrm{HgCl}_{4}{ }^{2-}$ に対して陰イオン交換樹脂 は非常に強い吸着能力を示し, $\mathrm{NaCl}$ が $1 \%$ 程度共存し ている場合でも図4に示すような吸着量があり，電解法 苛性ソーダ製造工場の排水処理に実用されている。その 他，陽イオン交換樹脂による $\mathrm{Cu}^{2+}, \mathrm{Zn}^{2+}, \mathrm{Ni}^{2+}$ などの 除去や，陰イオン交換樹脂による $\mathrm{CrO}^{2-}{ }_{4}$ の除去も実装 置が運転されている。イオン交換反応は反応速度が非常 に速く, 充填塔に対して 1 分程度の接触時間で通水処理 が可能である。イオン交換樹脂に吸着された有害物質は 薬品によって溶離され，有害物質は濃縮された溶液とな る。この溶液をそのままあるいはなんらかの処理をして 主工程へ再使用できれば理想的であるし，それが不可能 なときは沈殿法で処理する。イオン交換樹脂法に関して 


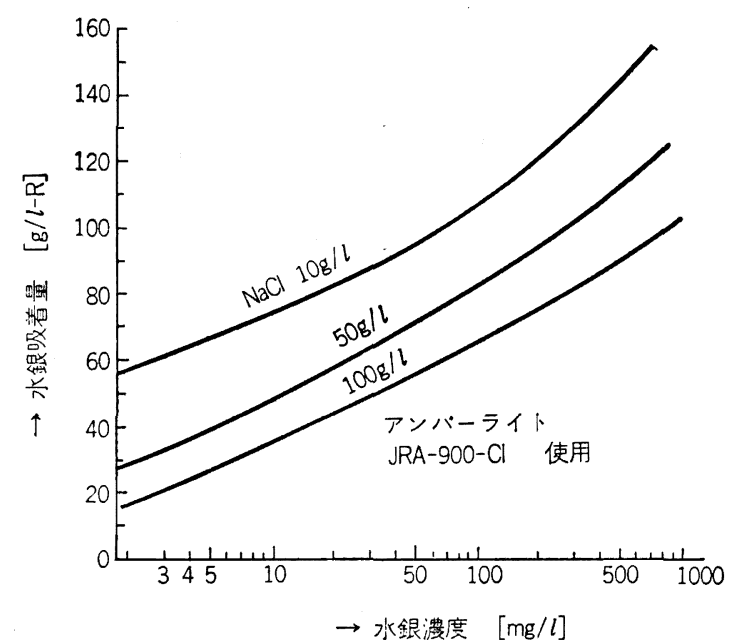

图 4 食㙁および水銀渺度による隆イオン交換樹脂 の吸着量の変化

は目的とする有害物質に対する選択性が最も重要な因子 であるが，選択性が大きいことは有害物質の除去の点か らは好都合であるが，逆に溶誰再生といら点からは不都 合になる。むまり選択性が大きすぎて溶離再生が実用上 不可能な場合もある。金属シフン錯塩の中にはこれに属 するものが多い。したがって溶㿥方法に充分な検討をし なければならない。

その他の吸着剤としては無機系の吸着剤, キレート樹 脂，ポリスチレンを母体とする合成吸着剤，油分吸着剤 などがあるが，粒状活性炭やイオン交換樹脂にくらべる と実用の籁囲は小さい。

吸着による除去方法は運転操作の簡単さが非常に大き な特徽である。吸着剤を塔に充埧して排水を通すといら だけで排水中の有窨物質が除去される。また排水の質や 量の変化に対しても他の方法よりは対応性が大きいこと も利点である。しかし充填塔や吸着剤など建設費が高価 になることが多いので最適装置の設計を慎重に考應しな ければならない。

\section{$2 \cdot 4$ 有害物質を膜で分離除去する方法}

$\mathrm{ED}$ (電気透析)， RO (逆浸透) はかん水を脱塩して 领料水または工業用水を作る技術である。ED の場合は 溶質である塩類を電気エネルギーによって膜を通過さ せ，ROでは逆に溶媒である水を圧力によって膜を通過 させる。

$\mathrm{ED}, \mathrm{RO}$ は有害物質の除去といらよりむ処理した排水 をさらに浄化して再使用するための 3 次処理に利用の主 目的が秥かれてきており，おそらく 中に 3 次処理技術として工業的に使用されはじめるので はないだろらか。

UF（超沪過）の原理は RO と同じであるが，使用す る膜の孔の大きさがより大きく, 分子サイズの大きい有
表 5 染色排水の処理法と効果

\begin{tabular}{|c|c|c|c|}
\hline 処 & 理 & COD 除去率 $[\%]$ & 色度除去率 [\%] \\
\hline \multicolumn{2}{|c|}{ オソンと活性峞 } & 70 & 90 \\
\hline \multicolumn{2}{|c|}{ オッンと擬集 } & 20 & 80 \\
\hline \multicolumn{2}{|c|}{ 凝棐と活性炭 } & 70 & 70 \\
\hline
\end{tabular}

機物を透過させないものである。UF は有害物質の除去 に使用される可能性を持っている。

膜による処理技術は非常に薄い膜を通して物質を移動 させるので，装置の設計製作や運転管理に関して充分な 技術的配虑が必要である。膜の污染を最低にするために はどうしたら良いか, 瞙の点検や交換をいかにやり易く するかなどである。

\section{3. 設計上の問題点}

排水はその質と量の経時変化が大きい。これにどう対 処するかが第 1 の問題点である。排水眝槽を充分大きく することは排水の質と量を平均化するのに役立つが, 経 費增となるし，また場合によっては腐敗するお去れるあ る。排水の質と量の变化を常に测定しながら処理条件を 制御することも，実際に行なおうとすると測定技術や制 御技術に未解決の点が少なくない。装直によっては運転 条件を大幅に変えることが非常に難しいこともある。こ の問題に対する対策としては常識的なことであるがまず 排水の排出状況をできるだけ正確に把握することが最重 要である。そして排水をできるだけ平均化するために, またできるだけ処理し易くするためにメインのプロセス を再恰討してみる。従来メインのプロセスは生産とい ら立場から組立てられてきているから，排水の排出とい ら立場から見值してみる訳である。一方有害物質除去ブ ロセスに関しては除去能力といら点と共に, 排水の変動 に対する除去能力の変動という点についてす評価してお かねばならない。両者で合格して始めて有害物質除去技 術として実用性が出て来る。

以上ををとめると，排水を平均化するためにメインの ブロセスを再検討する，使用しょらとする処理法の排水 変動に対する処理能力の変化を認識する, 処理法の許 容变化範囲内になるよら飞排水の貯槽を決める，とい ら手順になる。しかしこのことを充分に実施するため には相当の技術力と労力が要ることを付記しておきた い。

設計上の第 2 の問題点は処理技術の組合せの検討であ る。排水中には種々の有害物質が入っているので単一の 処理技術たけけで除去できることはむしろ少なく，二つ以 上の技術を組合せる場合が多い。また単一の有害物質を 除去する場合でる, 濃度の関係で組合せて使用すること がより合理的であることるある。従って全処理フロセス 
を設計する時，いくつかの処理技術の長短をよく認識し て扰く必要がある。特に種々の有機物を除去する場合に は, これらの有機物に対する各処理技術の除去能力は予 知できないことが多いので実験で確かめなければならな い。例学ばある染色工場の排水を処理する時, 表 5 のよ らな結果が得られたので，実装置はオン゙ンと粒状活性炭 の組合せを採用することに決定した。るた水銀を $1 \mathrm{ppm}$ 程度含有する排水をむずイオン交換樹脂で $0.02 \mathrm{ppm}$ 程 度に除去し，さらにテレート樹脂で検出されない程度に まで処理することも実用されている。

以上の 2 点が物理処理, 化学処理に上る有害物質除去 装置を設計する時の最重要問題である。物理処理, 化学
処理の各方法は原理的には既知のものばかりであり，工 業的にも広く使われているるのである。その意味で装置 を設計する時, ややるすれば簡単に考えがちであるが, 経時变化の大きい排水中から有害物質を除去する技術と して使用する場合には，また新しい観点にたって設計に あたることが必要である。

\section{参考文献}

1）化学工菜社，「水質污濁と防止技街」(1973)

2) 丸普,「化学便簿」(1965)

3）䖯江正治；オルガノハイライト，22，8(1973)

ii）活性スラッジ法による有害物質の分解除去*

\section{ま か がき}

微生物は元来, 自然界に存在する有機化合物を分解し てェネルギーを獲得し，增殖を行ない，同時にまた種々 の有機物を合成している。しかし，最近は有機化学工業 の急速な発展に伴ない微生物にとっては全然, 無関係な いろいろな有機化合物が数多く合成され，また農薬のよ らに意識的に微生物の生育を抑制したり，死隇させるよ らな有機化合物す合成され、これらが例えばDDTとか BHCのように 10 年以上も分解されず，土壤中に残留す ることがいま，環境上の大きな問題となってきている。

ここでは一般に有害と考学られている代表的な 2,3 の 有機化合物の活性スラッジ法による処理について述べる ことになっているが，今後は合成された有機化合物が生 物的に分解可能であるかどらかをあらかじめテストする ことも，新しい有機化合物を開発する上で必要になるた ろら。

\section{1. 活性スラッジ法の概要}

活性スラッシ法は図1のよらに廃水をまず，廃水貯槽 に導いて水量, 水質を調節し, $\mathrm{pH}$ の調節, $\mathrm{N}, \mathrm{P}$ の添加

* 昭和 48 年 3 月 22 日受理

** Hideo Ono 住文重嘰械エンパイロテック（株）
などを行ないながら一定量ずつ連続的に曝気槽に送る。 曝気槽では空気を吹き込みながら好気的な微生物の增殖 を計り，廃水中の有機物の分解と活性スラッジのフロッ クの生成を行なわせ，連続的に沈殿槽に導びき，フロッ クを沈殿させて上澄水を放流する。また，沈殿した活性 スラッジは一部を種スラッジとして曝気槽に返送し，一 部は余剩污泥として脱水，処分する。

この活珄スラッジ法の機作は図 2 のように懪気槽では Zoogloea をはじめ約 10 種類の土壤細菌が好気的な条件 の下で廃水中のいろいろな有機物を酸化して炭酸ガスと 水に分解するが，そのとき得られるエネルギーを利用し て增殖を行ない,フロックを生成して活性スラッシの微 生物集団ができるのである。

多くの産業廃水の活性スラッシ法による処理の結果を まとめてみると表 1 のらになる。すなわち，原廃水は BOD 2,000 ppm 以下に稀釈する方が 処理し易くなるこ とが多い。また，窒素とか燐酸の不足するすのについて は BOD に対して N と P の比が 100:5：1になるよう

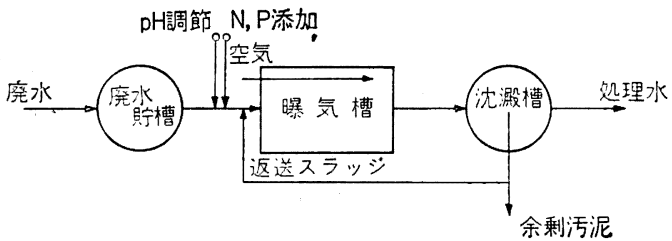

图1活性スラッ法の工程 